\title{
There Must be An Angel? Local Financial Markets, Business Angels and the Financing of Innovative Start-ups
}

\author{
Luca Grilli \\ Politecnico di Milano \\ Department of Management, Economics, and Industrial Engineering \\ Via R. Lambruschini 4b, 20156, Milan, Italy.
}

\begin{abstract}
This study addresses the question of whether business angels (BAs) can fill the gap left by venture capitalists (VCs) and banks in the financing of innovative start-ups in regions where there is a relatively thin financial supply of bank loans and VC investments. The empirical analysis based on c.a. 2,000 Italian ventures highlights that innovative start-ups located in weak local financial ecosystems show a relatively low probability to get BA financing: in these areas, angel investing is unlikely to represent a viable and effective informal solution to alleviate regional financing gaps towards innovative start-ups left by more institutionalized financial intermediaries.
\end{abstract}

JEL Codes: L26, G20, M13, R11.

Keywords: Innovative entrepreneurship; Business angels; Local financial markets; Venture capitalists; Banks; Italy. 


\section{INTRODUCTION}

The term Business Angels (BAs) refers to wealthy individuals, often former (successful) entrepreneurs, who professionally invest their own money into entrepreneurial ventures in return for an equity stake (or convertible debt) of the new company. They can operate alone or through ad-hoc networks of (BA) investors, and generally in addition to (seed and growth) capital they also provide coaching and advising function to the investees. Indeed, they often adopt a rather hands-on strategic attitude (e.g. Mason and Harrison, 2000).

If it is difficult to precisely quantify the role of this typology of investor, given its informal nature, available statistics point to an increasing weight and importance of BAs for the financing of entrepreneurial ventures in modern economies. Based on data from the Organisation for Economic Co-operation and Development (OECD, 2011), some scholars (e.g. Croce et al., 2018) pose an equivalence in terms of market size between BA and venture capital (VC) markets, both in the U.S. and in Europe. But BAs, likewise VCs, are selective investors. Thus, more revealing than the mere figures about the quantitative boundaries of the market are the names of some financed start-ups. American start-ups like PayPal and LinkedIn, but also (to a lesser extent) European entrepreneurial ventures like Body Shop or Innocent Smoothies, have benefited in their early stages from investments of BAs and have ultimately become rather successful companies in their field. Accordingly, BAs have increasingly attracted the attention of scholars in entrepreneurial finance (see the recent literature survey by Tenca et al., 2018). Broadly speaking, this literature highlights the positive role that BAs can perform in the financial eco-system, while at the same time, many areas still remain fairly unexplored or are just presumed and need further corroboration. Great difficulties in identifying this class of investors and the consequent lack of large and reliable micro-level data have certainly contributed to this indeterminacy (Mason and Harrison, 2000). In this respect, one possible view considers BAs as an important stage in the funding escalator model for innovative start-ups (Gregson, 2014; Roberts, 2015). Basically, most of these start-ups, especially at founding time, have primarily to rely on personal funds, those coming from the "3 Fs" (i.e. family, friends and fools) and/or bank 
debt (Colombo and Grilli, 2007) to finance their operations. While personal funds can be limited, bank debt is generally considered unfit for this typology of firms at their early stages (Carpenter and Petersen, 2002). The ultimate result is that a non-negligible fraction of promising start-ups might be financially constrained (Storey and Tether, 1998). In this respect, BAs are often positioned inbetween the "3Fs" stage and VC investors in the financial growth cycle of firms (see Berger and Udell, 1998, p. 623). By relaxing financial constraints and providing newly born start-ups with their financial resources and consultancy services, BAs are reputed to be able to nurture business prospects to the stage when they become appealing for more institutional investors, i.e. VCs (Madill et al., 2005). At that stage, having built throughout time a track record of performances and attraction of external investors, innovative start-ups may also more easily get access to other forms of capital, including debt and public equity. Adhering to this view, and also considering the prevalent local nature of potential financing sources for nascent ventures (Gompers and Lerner, 2001; Klagge and Martin, 2005), BA financing represents a much needed piece for the regional financial eco-system puzzle, that also benefits from the degree of development of the other financing sources. Without VCs, it is unlikely that BAs would prosper, since, among other reasons, angels would not have the possibility to easily monetize their initial investment. And at the same time, if the banking system is poorly developed, entrepreneurial ventures may not be able to finance neither their day-to-day nor long-run operations, limiting their growth possibilities. As a result, the absence of a local florid financial eco-system made by VCs and banks would hamper the probability for an innovative startup to obtain a BA investment.

Conversely, one may think that BA financing represents an informal remedy to deficiencies in the local financial eco-system that is triggered rather than hampered by the weaknesses of more institutional financial operators in that context. In this case, the financial 'institutional void' (Khanna and Palepu, 1997) left by VCs and banks towards the financing of innovative start-ups could represent an 'opportunity space' (Mair and Marti, 2009, p. 422) for BAs rather than an obstacle. Allegedly, an innovative start-up would be more likely, ceteris paribus, to receive a BA investment in those local 
contexts characterized by the scarce presence of VCs and banks. BAs would help alleviating funding gaps by seizing missed opportunities left by VCs and banks.

The present study aims at shedding light on which of these two alternative arguments finds more merit, and it addresses the following research question: Can business angels fill the gap left by VCs and banks in geographical areas where there is poor availability of VC and bank financing? By analysing the Italian context, we investigate if innovative start-ups are more likely to be funded by BAs in regions characterized by a florid financial eco-system in terms of supply of financing sources from other institutional actors, i.e. VC investors and banks. In doing so, to the best of our knowledge, this analysis is the first to deal with this issue by using a large fine-grained survey database at firmlevel, composed by both BA-backed and non BA-backed innovative start-ups. Despite its importance from a regional policy perspective, evidence on this topic is still rather scant. Admittedly, at territorial level, the (thin) extant literature seems more supportive of a synergetic role of BA with respect to VC (e.g. Harrison and Mason, 2000). But at a more micro level, it is still unclear whether an innovative start-up, controlling for founding-team characteristics, can have more or less probability to be financed by BAs in relation to the conditions of the local financial eco-system. The exploration of this issue is of great interest for policy makers who aim at favouring the regional innovative entrepreneurialism. In fact, it helps shedding light on whether funding gaps suffered by innovative start-ups (Colombo and Piva, 2008; Grilli, 2014) can be better alleviated by adopting a comprehensive and holistic policy perspective that embraces all the different stages of the funding escalator. Or conversely, it may even suggest that the equity gaps of innovative start-ups (Veugelers, 2011) is an overemphasized problem, since informal remedies may always endogenously arise at the local level to alleviate the financing constraints of innovative start-ups. In this respect, our test-bed makes even more compelling the investigation at stake, especially from a policy perspective. In fact, Italy is characterized by a relatively high degree of heterogeneity in terms of regional financial eco-systems conditions; while at country level, discounted the regional disparities, it is possible to assert that VC supply is very thin in comparison with other national economic systems (e.g. Bertoni et al., 2016; 
2018). Moreover, Italian innovative start-ups generally face substantial (equity and debt) financing constraints (e.g. Colombo and Grilli, 2007), which are reputed to seriously hinder their performances. Therefore, for these reasons, it is a question of stringent relevance for policy makers to know whether BAs can fill the gaps left by VCs and banks, so to rightly direct their efforts in the design of entrepreneurship policies, particularly so in the most disadvantaged areas of the country.

The remainder of the paper is structured as follows. In the next section we formulate hypotheses about how BAs’ activity is affected by the regional financial eco-system. In Section 3 we describe the dataset, define the econometric methodology, portray the model(s) specifications and illustrate some descriptive statistics. Section 4 presents the results of the empirical analysis, while the robustness checks that were run to further corroborate the test of the hypotheses are presented in the On-line Appendix. Finally, findings do offer us the opportunity in Section 5 to draw concluding remarks and implications for theory and policy making.

\section{BUSINESS ANGELS IN THE REGIONAL FINANCIAL ECO-SYSTEM}

Grounding on the literatures on institutions and entrepreneurial finance, two sets of hypotheses can be advanced in addressing the research question on whether BAs are able to fill the regional financial gap left by VCs and banks.

The first one sees this typology of investors performing a much needed role in a well-functioning local capital market: in this case, BAs would serve the needs of innovative start-ups in a specific and delimited phase of their life cycle, which otherwise would be unmet; and at the same time, the specific beneficial action of BAs would be enabled by the embedment in a florid local financial eco-system. In the funding escalator (Gregson, 2014; Roberts, 2015) and financial growth cycle (Berger and Udell, 1998) models, despite of some variations (Gregson et al., 2013), the BA’s stage is represented by the life phase where the start-up has not entered any market yet. The focus is on the feasibility tests of the business idea. Involved investments are highly uncertain and, often, limited in size. In this 'proofof-concept' and embryonic phase, BAs are reputed to be more suitable investors than institutional 
financial intermediaries such as banks and VCs. On the one hand, a large body of literature identifies banks (Carpenter and Petersen, 2002) as institutions suffering from too severe asymmetric information problems for being viable financiers of innovative start-ups. Banks are deemed not to possess the required competencies needed both to assess the goodness of the projects proposed by innovative entrepreneurs and to monitor and coach these investments effectively ex-post (Himmelberg and Petersen, 1994). While the issues of adverse selection and moral hazard caused by asymmetric information could be partially attenuated by the availability of collateral assets by firms (Berger and Udell, 1998), these instruments are rare for innovative start-ups, which typically base their businesses in intangible assets that are ineffective in that respect. On the other hand, VCs, by their own nature, are almost unreachable targets for embryonic businesses: VC investors deliberately neglect small investments (Gompers and Lerner, 1999; Wasserman, 2017), usually acquire nonnegligible equity stakes in the ventures they back (De Clercq et al., 2006) and use formal methods of control of their investments (Wong et al., 2009).

In this view, the financing of BAs would be considered by an innovative start-up a crucial step in its ladder of investment. The BA investment could be instrumental to test waters and, if tests' results are positive, attract later larger financing rounds from more institutional players. In fact, VCs would eventually become interested and the innovative start-up could more easily access bank debt channels once uncertainty is at least partly reduced. Consequently, according to this view, an innovative entrepreneur would be more likely to access BA financing in a florid regional financial eco-system. From the demand-side, innovative start-ups may be more likely to self-select out in thin equity markets (Bertoni et al., 2016) and “difficult-to-access” bank loan markets (Kon and Storey, 2003). Thus, they could be forced to opt for sub-optimal self-financing strategies (Giudici and Paleari, 2000; Colombo and Grilli, 2007), especially after the great financial crisis (Cowling et al., 2016). On the supply-side, the BA segment could be favoured by the presence of an advanced bank system which may provide sophisticated and personalized private banking services to wealthy individuals and help them in portfolio selection and management (Beaverstock et al., 2013). Secondly, a solid local VC 
industry is also likely to be advantageous. Harrison and Mason (2010) identify several different reasons why BAs and VCs can benefit each other: VCs can scale and bring to profitability the BAbacked start-ups; BAs can generate more proved targets to be developed by VCs; they both can invest together in deals; and what seems really important, co-location between BAs and VCs can increase deal referral to the benefit of entrepreneurs seeking finance. In a similar vein, relevant benefits my arise for BAs when their backed start-ups access more easily (and at lower interest rates) banks loans (Avdeitchikova and Landström, 2016, p. 65).

Accordingly, this first view translates into the two following research hypotheses:

H1a. The probability for an innovative start-up to obtain investment from Business Angels increases, ceteris paribus, if the start-up is located in a region with a highly developed bank system.

H1b. The probability for an innovative start-up to obtain investment from Business Angels increases, ceteris paribus, if the start-up is located in a region with a highly developed VC sector.

Conversely, the opposite approach could see BAs as an "endogenous" solution to the deficiency of institutional investors in financing innovative start-ups. In this case, angel investing would represent a sort of informal response to the incapacity of other financiers to seize potentially profitable investment opportunities in markets. Consequently, the scarce development of alternative sources of financing for innovative start-ups (i.e. banks and VCs) could augment the set of profitable targets for BAs, increase the bargaining power of these latter towards innovative entrepreneurs (Mason and Harrison, 2015), and thus lead to an increase in their informal investment activity.

By adopting this perspective, the weakness of formal financial intermediaries would represent a "void” in the financial ecosystem that BAs could be ready to fill. Studies in institutional economics have largely emphasized how important "institutional voids" are in shaping economic outcomes (Fama, 1980; North, 1990). Institutional voids can be seen as both constraints that limit the development of an economic system, but also as profitable opportunities for those economic agents 
who are able to recognize them and provide solutions to these institutional deficiencies (Khanna and Palepu, 1997; Chakrabarty, 2009). For example, an 'institutional void in financial credit availability’ (Fligstein, 1990; Chakrabarty, 2009) is considered one of the main reason behind the dominance of family-owned firms in several economic systems (Stearns and Allan, 1986; Khanna and Palepu, 2000). As well explained by Chakrabarty (2009, p. 35), the weakness of entrepreneurial finance ecosystem may pose some types of agents (i.e. rich families) in a privileged position to exploit these voids at their own advantage (i.e. purchase of greater ownership stocks). In the same vein, we claim that a similar mechanism might be in place for what concerns angel financing. According to this stance, an innovative start-up would be more likely to become BA-backed the less developed the regional financial eco-system is. In fact, from the demand-side, the lack of viable institutional financing alternatives, i.e. VC investments and bank loans, would push entrepreneurs to search for more informal ways of financing their start-ups and make them more keen on accepting the BAs' offer terms. From the supply-side perspective, BAs could take advantage of this and perform the role of entrepreneurial economic agents able to fill the financing void left by institutional investors. The case of Body Shop is emblematic in this respect, since the BA investment was triggered by the refusal of a bank to grant a loan. The founder Anita Roddick wanted to open a second shop in 1976, but the bank turned down her request for a loan. The BA Ian McGlinn, proposed her an offer of $£ 4,000$ in return for $50 \%$ equity in the company. The offer was accepted, allowing McGlinn to sit on the company's board of directors. In turn, he contributed to the Body Shop’s development and success, resigning just before the IPO of the company in 1984 (Daily Mail, 2010).

On the basis of the aforementioned perspective about the role of BAs as void fillers, we posit the following two alternative hypotheses with respect to hypotheses H1a and H1b:

H2a. The probability for an innovative start-up to obtain investment from Business Angels decreases, ceteris paribus, if the start-up is located in a region with a highly developed bank system. 
H2b. The probability for an innovative start-up to obtain investment from Business Angels decreases, ceteris paribus, if the start-up is located in a region with a highly developed VC sector.

\section{SAMPLE AND METHDOLOGY}

\subsection{Data collection}

This study takes advantage of a survey launched by the National Committee of the Italian Ministry for Economic Development (MISE) on the "Monitoring and Evaluation of National policies for the Eco-system of Italian Innovative Start-ups” and administered by the Italian National Institute of Statistics (ISTAT) in April-May 2016. The questionnaire was aimed at collecting information on Italian innovative start-ups along a series of dimensions including the human capital endowment of the founding teams, the financial structure of these new ventures and their innovation strategies and, ultimately, entrepreneurs' assessment of the public policy measures that were put in place in this domain. In fact, in the late year 2012, the Italian Government issued a law (Law no. 221/2012, modified by further amendments, the so-called Italian Startup Act) introducing the possibility for innovative start-ups to qualify themselves as young innovative companies (YICs). This status was and still is reserved to limited liability companies (either Italian companies or branches of EU companies registered in Italy), which are younger than 6 years (at the end of the sixth year their status as YIC ceases along with the possibility to obtain benefits), operate in high and medium technologyrelated businesses, and have an innovative content (see the On-line Appendix for insights on the law).

The questionnaire targeted the whole population of Italian YICs, which was equal to 5,150 innovative start-ups as of December 2015. The questionnaire was filled with partial or complete information by 2,275 YICs, leading to a considerable 44\% response rate. The sample is ensured to be representative of the population on all dimensions on which ISTAT has information on both sides, i.e. population and sample, including firms’ geographic location, industry affiliation, age and legal status (see MISE 2016, for further details). For what concerns this study, our main focus is on Section 2 of the questionnaire, about start-ups' financing structure, where entrepreneurs were asked to 
indicate the different nature of the firm's shareholders, both at founding and at survey time. More particularly, they were surveyed whether business angels figured among shareholders (and their quota shares) at foundation and at the moment of the survey. In line with the prevalent view about this typology of formal investors (Shane, 2012), a rather narrow definition was adopted (and communicated to the respondents), where BAs are considered high net-worth private individuals who provide financial capital by investing a portion of their assets in high-risk entrepreneurial ventures in which they do not have any family connection, with the aim of obtaining a return in the medium-term (e.g. 7 years) by selling their initial stake (Freear et al., 1992). This information was complemented with data on founding teams' endowment in terms of human capital (Section 1 of the questionnaire), and was then anchored to public-available regional data on the local financial eco-system and other dimensions to perform the econometric testing of our hypotheses. Overall, 126 firms out of 2,184 start-ups indicated the presence of (at least) a business angel within the shareholders, of which 73 at foundation. Whether this ratio of BA-backed Italian innovative start-ups can be considered high or low is debatable. However, what is certain is that this number, apart from probably being affected by the strict definition adopted in the survey, totally reflects the thinness of the Italian venture capital market (Bertoni et al., 2006). Table A2 in the On-line Appendix presents the geographical distribution of BA-backed start-ups both at foundation and at survey time, along with densities of investments across regions (percentage of BA-backed YICs out of the total number of YICs). BAs surely appear more active in the North-West of the country (specifically in Lombardia), albeit looking at densities, no clear pattern emerges in terms of frequency of BA investments across regions. As a matter of facts, almost none of the regions (with the exception of Trentino Alto Adige and Valle D'Aosta) exceeds the thresholds of $10 \%$ of BA-backed active start-ups, both at foundation and at survey time, with comparable percentages across (sometimes very) different territories. We will test in the next Sections whether similarities and differences in these patterns are influenced by the degree of development of local financial eco-systems. 


\subsection{The specification of the econometric analysis}

First, a series of probit models were estimated in order to test if the probability for a YIC to obtain financing from BAs is positively (as predicted by H1) or negatively (as predicted by H2) influenced by the degree of development of the local financial eco-system within which an innovative start-up is incepted. Secondly, a series of double-censored tobit regressions was used to further corroborate the test of the hypotheses with models where the dependent variable is the percentage of shares owned by the BA(s) in the venture. Given the boundaries in the distribution of the dependent variable, analogously to other studies in related fields (e.g. Kortum and Lerner, 1998; Audretsch and Lehmann, 2004; Colombo and Grilli, 2007) we opted for a censored model. Nonetheless, it is worth noting that ordinary least squares estimations lead to similar findings. For sake of completeness, probit and tobit analyses were run considering the eventual presence of BAs among shareholders both at founding time and at the moment the survey was administered. Independent variables used in the analyses and their detailed definitions are also provided in Table A3 in the On-line Appendix.

\subsubsection{Independent variables}

The independent variables of interest are represented by two distinct measures. The first variable is Local Bank System Development, which captures the yearly amount of bank credit loans over GDP granted to firms in the region of interest (NUTS 2 level) and averaged across the four years (20082011) preceding the implementation of the Italian Startup Act (source: ISTAT). Analogously, Local VC Development is a variable capturing the yearly amount of venture capital investments over GDP flown in the region of interest (NUTS 2 level), again averaged across the four years (2008-2011) preceding the implementation of the Law (Source: ISTAT). The choice of NUTS 2 as the most appropriate geographical level to capture the conditions of the local financial eco-system within which the Italian YICs are embedded is indeed well-supported by the literature in the field, as to what concerns VC (e.g. Bertoni et al., 2016; 2018) and bank financing (e.g. Hasan et al., 2009).

\subsubsection{Regional-specific control variables}


Following Avdeitchikova (2009), we control for the specialization in high-tech industries of the region of the start-up and on the entrepreneurial vocation of regions. In particular, the variable Hightech Industry represents the number of residents employed in high-tech and knowledge-intensive manufacturing sectors as a percentage of the total workforce of the region (source: ISTAT). Again the variable has been averaged across the four years preceding the implementation of the Law. The Entrepreneurial Activity Index, i.e. TEA, sourced from the Global Entrepreneurship Monitor (GEM), is also introduced into model specifications in order to control for different entrepreneurial rates (in all sectors) across different regions at the firm's foundation year. Finally, regressions also include a series of macro-regional dummies (at NUTS 1 level, i.e. Northwest, Northeast, Centre, South and Islands) in order to control for possible relevant unobserved heterogeneity at the geographical level (without incurring in any dummy variable trap).

\subsubsection{Founding team-specific control variables}

Likewise VC investments (e.g. Tyebjee and Bruno, 1984), BAs’ decision to invest in start-ups is found to be strongly dependent on founders' characteristics and in particular on the human capital endowment of entrepreneurs (Tenca et al., 2018). Especially in high-tech and knowledge intensive sectors, human capital is the primary asset for the success of newly created ventures (Cooper and Bruno, 1977; Colombo and Grilli, 2005; Grilli, 2014) and failure to control for such important characteristic may lead to biased results in our context. In this respect, grounding on the seminal distinction between the generic and the specific components of human capital (Becker, 1964), and following the consolidated empirical literature on the topic (Colombo and Grilli, 2005), we define the following two covariates. Generic Human Capital is the average number of years of experience among co-founders of the same firm gained through education and work experience in other sectors with respect to the activity of the start-up. Specific Human Capital is the average number of years of experience among co-founders of the same firm gained through work experience in the same sector of the start-up and previous managerial and entrepreneurial experiences. 
Then, we also add two variables which can influence entrepreneurs' ambitions and, thus, exert an impact on angel financing. More specifically, the variable Parent Entrepreneur measures on average how many co-founders have parents who are (or were) entrepreneurs. The parent role model is considered important not only for the career choice of entrepreneurs (Blanchflower and Oswald, 1990) but also for determining their proactive behaviour, and ultimately, their aspirations (Crant, 1996). Ambitious thinking is also associated to entrepreneurs with a worldwide perspective and a “think big” attitude (Dyer et al., 2008) which may be influenced by the international experience of founders. For this purpose, International Experience is an averaged index across co-founders that ranges from 0 to 3 and counts if the entrepreneurs have matured any experience in a foreign country as an enrolled student, a pay-roll employee and an entrepreneur.

Furthermore, since female entrepreneurs appear more reluctant than male entrepreneurs in seeking angel financing (Becker-Blease and Sohl, 2007), we also control for gender (see Tenca et al., 2018 for a discussion) with the covariate Male Founders, which is the percentage of male co-founders. Lastly, Team Size represents the number of founders of the innovative start-up.

\subsubsection{Other control variables}

We also include in the econometric analyses several other variables that may impact the dynamics at stake. At the firm-level, Incubation is a dummy variable capturing whether the start-up has ever been located in a certified business incubator or not. Then, we discriminate the legal nature of the innovative start-ups by separating limited liability companies ( $S R L)$, from other partnerships. At the industry level, a series of NACE 2 sectoral dummies are always included in the estimates. At macrolevel, GDP per capita is the gross domestic product converted to dollars using purchasing power parity rates and divided by total population.

\subsection{Descriptive statistics}

Table A4 in the On-line Appendix reports descriptive statistics and the correlation matrix of the independent and control variables used in the econometric analyses. On average, YICs are located in regions characterized by intensities of VC investment and bank loans equal to $0.005 \%$ and $61 \%$ of 
GDP, respectively. Inter-regional heterogeneity is sufficiently high to provide a well-suited test-bed for our hypotheses and it does not strictly mirror a North-South divide pattern, even if it is of course influenced by it (this will be the subject of a specific robustness check). In fact, the minimum value of Local Bank System Development refers to Calabria (38.8), while the lowest of Local VC Development is for Veneto (0.0005). Maximum values belong to Lombardia (77.3) for the former variable and to Lazio (0.016) for the latter one. Finally, a variance-inflation factors (VIFs) test excludes any multi-collinearity concern since all VIFs take a value far below 3 (Mean VIF equal to 1.4) where, as a general rule of thumb, a value above 10 may indicate the possible presence of a serious multi-collinearity problem in the estimates (Kennedy, 2003).

\section{RESULTS}

Results of the main empirical investigation are exposed in Table 1 on the full-information sample (i.e. 2,184 innovative start-ups) and in Table 2 on a reduced (due to some missing values) sample size including all control variables (i.e. 1,726 innovative start-ups). In both tables, Columns I and II refer to firms at their founding time and report estimates from the probit and tobit models, while Column III and IV report probit and tobit models on the firm information at the survey time.

[Table 1]

[Table 2]

All the estimates bring solid support to hypotheses H1a and H1b, in contrast with hypotheses H2a and H2b that argued about a possible “void filler” role of angel financing. In fact, both variables Local Bank System Development and Local VC Development always show a positive and statistically significant coefficient in all regressions, pointing to a positive impact of the local financial system, both from the bank and VC sides, on the probability for an innovative start-up to obtain an investment from (at least) a BA and on the percentage of company's shares held by BAs. These effects are not only statistically significant but they are also relevant from an economic point of view (see also Table A5 in the On-line Appendix for marginal effects and semi-elasticities). Taking as benchmark probit 
estimates of Table 1-Column III, holding the other covariate constant at its mean value, an increase of the Local Bank System Development variable from its $10^{\circ}$ to the $90^{\circ}$ percentile brings the probability to be financed by BAs from $2.6 \%$ to $7.5 \%$, which represents ceteris paribus an increase of $+191 \%$ in the probability to be financed by BAs. A lower but still remarkable effect is traceable for Local VC Development where the same exercise as before leads to an increase of $+111 \%$ in the probability to be financed that goes from 3.7\% to $7.8 \%$. Looking at the tobit estimates of Table 1Column IV, conditioning on receiving BA financing, moving from a low developed local financial eco-system to a highly developed one leads to an increase in the expected value of the percentage of shares held by BAs from $20.7 \%$ to a remarkable $26.6 \%$.

Let us now briefly consider the effect of control variables in Table 2. Both the regional high-tech intensity and the total entrepreneurial activity of a region always show a negative (albeit never significant) impact on YICs’ access to BA financing, revealing how angel capital is neither driven by regional entrepreneurship rates tout court nor necessarily determined by the regional density of existing firms in high-tech industries. These results echo those of other studies in the entrepreneurial finance literature that highlight how these dimensions do not always strongly affect VCs' activism (e.g. Félix et al., 2013). Founding team-specific control variables appear to exert a more nuanced influence. While founders' human capital is found to be weakly related to BA financing suggesting that both the wealth and capability effects of human capital (e.g. Colombo and Grilli, 2005) may limit highly-skilled and wealthy entrepreneurs' willingness to search for other external individual shareholders, the international experience of entrepreneurs is always found to significantly affect the dependent variables. Then, in line with the studies highlighting a lower access by women-owned businesses to angel capital (e.g. Becker-Blease and Sohl, 2007), teams formed by several founders which are prevalently males show a greater capacity to involve BAs in their start-up, whether at foundation or later on. While, the impact of the variable related to the parental role model is instead less neat, since Parent Entrepreneur exhibits a positive but always insignificant impact on the capacity of an innovative start-up to obtain a BA investment. Among the firm-specific controls, 
interestingly, the variable Incubation always shows a positive and statistically robust coefficient; while the legal nature of the start-up does not seem to exert a great explanatory power neither on a start-up’s probability to access BA financing nor on the quota shares held by BAs.

Results have been subjected to several tests in order to gauge the reliability of the findings. For sake of space, we report them in the On-line Appendix.

\section{CONCLUSIONS}

One of the most successful and often cited cases of BA financing, the Body Shop story in the midseventies, started from a bank loan denial to the founder Anita Roddick. More generally, the literature on institutional economics (North, 1990) and on institutional voids (Khanna and Palepu, 1997) suggests the idea that informal investing could at least partly alleviate start-ups' financial constraints which also stem from firms' hurdles to access more formal channels of financing. This view contrasts with the opposite perspective that deems angel capital as a (fundamental) piece of a more complex puzzle and, ultimately, one of the first stepping stones in the financial growth cycle of a start-up. The view that considers BA financing as highly interconnected with the other possible sources of financing (Berger and Udell, 1998) and ultimately embedded in specific (local) financial eco-systems has also been very highly regarded in the entrepreneurial finance literature (e.g. Wetzel, 1994; Madill et al., 2005).

Whether both perspectives can be equally plausible in theory, large empirical evidence on this issue is still lacking, especially when it is based on large firm-level micro datasets. This paper aims at contributing to fill this gap, by analysing the Italian context of innovative start-ups. Our empirical analysis run on a sample of nearly 2,000 innovative start-ups created in Italy in-between 2009 and 2015 highlights that the firm-specific probability to obtain a BA investment is significantly lower for an innovative start-up if this latter is located in a weak regional financial eco-system. Conversely, BAs invest more in start-ups (and acquire more shares from investees) if the focal innovative start- 
up is located in regions characterized by a florid financial eco-system, in terms of supply of funds from either VCs or banks.

These results hold across several controls and are robust to a large battery of econometric checks. Obviously, they are not immune from limitations which however open up avenues to future research. First, the tobit analysis here performed aims at only confirming the probit one, yet it does not really allow to dig into possible differences between the drivers of the investment decision by BAs and the factors affecting their choice of how much to invest. Specifically, a lack of sufficient data with positive values on the eventual second stage and the absence of viable exclusionary restrictions, prevent us from running a reliable Heckman two-steps analysis. Similarly, we are unable to distinguish from an empirical point of view the relevance of demand-side vs. supply-side motives behind the final choices of BAs. We also leave to future research endeavours the search for possible moderating factors of all these dynamics. For example, the non-significance of some geographical controls (e.g. regional high-tech specialization) may conceal some interaction or threshold effects with our independent variables that it is worthwhile to be further investigated.

Nonetheless, we believe that these findings respond to the call for more micro-level research on informal financing (e.g. Webb et al., 2013; Wu et al., 2016) and do contribute to enhancing our understanding of the trade-offs and complementarities in the entrepreneurial finance domain arising from angel capital and the regional financial eco-system within which entrepreneurial ventures are embedded. Besides, they have interesting implications for both entrepreneurs and managers of startups and policy makers. To the former it is shown that the probability to find informal investing cannot be disjointed by the conditions of the local financial environment, and that the embedment in a weak eco-system will also likely lead to difficulties in accessing alternative informal sources of financing. In this respect, crowdfunding appears much less geographically constrained (Agrawal et al., 2014) and, thus probably, represents a more viable way out from the lack of financing for innovative startups created in disadvantaged areas. From a policy-making perspective, this study highlights how it is extremely unlikely that capital markets will endogenously find mechanisms and solutions to their 
eventual imperfections. The idea that frictions in some parts of the financial growth cycle can just open new horizons for a different typology of actors, thus overall, not damaging too much social welfare, does not find corroboration from our analysis. While instead, these results point to the need from a regional social welfare perspective to tackle entrepreneurial finance issues with a more holistic policy approach, especially in regions characterized by a weak financial eco-system. Single ad-hoc indirect policy measures aimed at incentivizing external investors risk to exert a limited impact if applied to weak local financial eco-systems. In financially weak regions, more systemic and handson approaches are probably needed in the long-run than just the offer of short-term (often sporadic) tax reductions to specific categories of investors. In strong regions, if these measures may surely have some merits, nonetheless policy makers have always to carefully check the capacity of such policy interventions to produce truly additive results in the local financial eco-system and not mere vicious “Matthew effects” (Antonelli and Crespi, 2013).

Acknowledgements: This study has greatly benefited from the comments offered by the Guest Editors, Tomasz Mickiewicz, Boris Mrkajic and three anonymous reviewers. Responsibility for any errors lies solely with the author. 


\section{References}

Agrawal, A., Catalini, C., \& Goldfarb, A. (2014). Some simple economics of crowdfunding. Innovation Policy and the Economy, 14(1), 63-97.

Antonelli, C., \& Crespi, F. (2013). The "Matthew effect" in R\&D public subsidies: The Italian evidence. Technological Forecasting and Social Change, 80(8), 1523-1534.

Audretsch, D.B. \& Lehmann, E.E. (2004). Financing high-tech growth: The role of banks and venture capitalists. Schmalenbach Business Review, 56, 340-357.

Avdeitchikova, S. (2009). False expectations: Reconsidering the role of informal venture capital in closing the regional equity gap 1. Entrepreneurship and Regional Development, 21(2), 99-130.

Avdeitchikova, S., \& Landström, H. (2016). The economic significance of business angels: Toward comparable indicators. Handbook of Research on Business Angels, edited by Colin Mason and Hans Landström, Cheltenham, UK: Edward Elgar, 53-75.

Beaverstock, J.V., Hall, S., \& Wainwright, T. (2013). Servicing the super-rich: New financial elites and the rise of the private wealth management retail ecology. Regional Studies, 47(6), 834-849.

Becker, G. (1964). Human Capital. National Bureau of Economic Research. New York.

Becker-Blease, J. R., \& Sohl, J. E. (2007). Do women-owned businesses have equal access to angel capital?. Journal of Business Venturing, 22(4), 503-521.

Berger, A. N., \& Udell, G. F. (1998). The economics of small business finance: The roles of private equity and debt markets in the financial growth cycle. Journal of Banking \& Finance, 22(6), 613673.

Bertoni, F., Colombo, M.G., Croce, A., \& Piva, E. (2006). A review of the venture capital industry in Italy. In Gregoriou, G.N., Kooli, M., Kraeussl R. (Eds.), Venture capital in Europe. Elsevier: Amsterdam.

Bertoni, F., D’Adda, D., \& Grilli, L. (2016). Cherry-picking or frog-kissing? A theoretical analysis of how investors select entrepreneurial ventures in thin venture capital markets. Small Business Economics, 46(3), 391-405. 
Bertoni, F., D’Adda, D., \& Grilli, L. (2018). Self-selection of entrepreneurial firms in thin venture capital markets: theory and empirical evidence. Strategic Entrepreneurship Journal, forthcoming.

Blanchflower, D., \& Oswald, A. J. (1990). What makes an entrepreneur? Evidence on inheritance and capital constraints (No. w3252). National Bureau of Economic Research.

Carpenter, R. E., \& Petersen, B. C. (2002). Capital market imperfections, high-tech investment, and new equity financing. The Economic Journal, 112(477), F54-F72.

Chakrabarty, S. (2009). The influence of national culture and institutional voids on family ownership of large firms: A country level empirical study. Journal of International Management, 15(1), 32-45.

Colombo, M. G., \& Grilli, L. (2005). Founders' human capital and the growth of new technologybased firms: A competence-based view. Research Policy, 34(6), 795-816.

Colombo, M. G., \& Grilli, L. (2007). Funding gaps? Access to bank loans by high-tech start-ups. Small Business Economics, 29(1-2), 25-46.

Colombo, M. G., \& Piva, E. (2008). Strengths and weaknesses of academic startups: a conceptual model. IEEE Transactions on Engineering Management, 55(1), 37-49.

Cooper, A. C., \& Bruno, A. V. (1977). Success among high-technology firms. Business Horizons, 20(2), 16-22.

Cowling, M., Liu, W., Minniti, M., \& Zhang, N. (2016). UK credit and discouragement during the GFC. Small Business Economics, 47(4), 1049-1074.

Crant, J. M. (1996). The proactive personality scale as a predictor of entrepreneurial intentions. Journal of Small Business Management, 34(3), 42-49.

Croce, A., Guerini, M., \& Ughetto, E. (2018). Angel financing and the performance of high-tech startups. Journal of Small Business Management, 56(2), 208-228.

Daily Mail (2010). How a £4,000 Body Shop loan made £146m. 26 June 2010.

De Clercq, D., Fried, V. H., Lehtonen, O., \& Sapienza, H. J. (2006). An entrepreneur's guide to the venture capital galaxy. The Academy of Management Perspectives, 20(3), 90-112.

Dyer, J. H., Gregersen, H. B., \& Christensen, C. (2008). Entrepreneur behaviors, opportunity recognition, and the origins of innovative ventures. Strategic Entrepreneurship Journal, 2(4), 317338.

Fama, E. F. (1980). Agency problems and the theory of the firm. Journal of Political Economy, 88(2), 288-307.

Félix, E. G. S., Pires, C. P., \& Gulamhussen, M. A. (2013). The determinants of venture capital in Europe - Evidence across countries. Journal of Financial Services Research, 44(3), 259- 279.

Fligstein, N. (1990). The Transformation of Corporate Control. Harvard University Press, Cambridge, MA. 
Freear, J., Sohl, J. E., \& Wetzel, W. E. (1992). The investment attitudes, behaviour and characteristics of high net worth individuals. In Frontiers of entrepreneurship research, ed. N.C. Churchill, S. Birley, W.D. Bygrave, D.F. Muzyka, C. Wahlbin, and W.E. Wetzel, 374-87. Wellesley, MA: Babson College.

Giudici, G., \& Paleari, S. (2000). The provision of finance to innovation: a survey conducted among Italian technology-based small firms. Small Business Economics, 14(1), 37-53.

Gompers, P. A., \& Lerner, J. (1999). What drives venture capital fundraising? (No. w6906). National bureau of economic research.

Gompers, P. A., \& Lerner, J. (2001). The venture capital revolution. Journal of Economic Perspectives, 15(2), 145-168.

Gregson, G. (2014). Financing New Ventures: An Entrepreneur's Guide to Business Angel Investment. Business Expert Press.

Gregson, G., Mann, S., \& Harrison, R. (2013). Business angel syndication and the evolution of risk capital in a small market economy: evidence from Scotland. Managerial and Decision Economics, 34(2), 95-107.

Grilli, L. (2014). High-Tech Entrepreneurship in Europe: A Heuristic Firm Growth Model and Three “(Un-) easy Pieces” for Policy-Making. Industry and Innovation, 21(4), 267-284.

Harrison, R. T., \& Mason, C. M. (2000). Venture capital market complementarities: the links between business angels and venture capital funds in the United Kingdom. Venture Capital: An International Journal of Entrepreneurial Finance, 2(3), 223-242.

Hasan, I., Koetter, M., \& Wedow, M. (2009). Regional growth and finance in Europe: Is there a quality effect of bank efficiency?. Journal of Banking \& Finance, 33(8), 1446-1453.

Himmelberg, C. P., \& Petersen, B. C. (1994). R\&D and internal finance: A panel study of small firms in high-tech industries. Review of Economics and Statistics, 76(1), 38-51.

MISE (2016). Relazione Annuale 2016 al Parlamento Italiano. Available at: http://www.mise.gov.it.

Kennedy, P. (2003). A Guide to Econometrics, 5th ed. Blackwell Publishing. Oxford.

Khanna, T., \& Palepu, K. (1997). Why focused strategies may be wrong for emerging markets. Harvard Business Review, 75(4), 41-48.

Khanna, T., \& Palepu, K. (2000). The future of business groups in emerging markets: Long-run evidence from Chile. Academy of Management Journal, 43(3), 268-285.

Kon, Y., \& Storey, D. J. (2003). A theory of discouraged borrowers. Small Business Economics, 21(1), 37-49.

Kortum, S., \& Lerner, J. (1998). Does venture capital spur innovation? (No. w6846). National Bureau of Economic Research. 
Li, Y., \& Zahra, S. A. (2012). Formal institutions, culture, and venture capital activity: A crosscountry analysis. Journal of Business Venturing, 27(1), 95-111.

Madill, J. J., Haines, Jr, G. H., \& RIding, A. L. (2005). The role of angels in technology SMEs: A link to venture capital. Venture Capital, 7(2), 107-129.

Mair, J., \& Marti, I. (2009). Entrepreneurship in and around institutional voids: A case study from Bangladesh. Journal of Business Venturing, 24(5), 419-435.

Mason, C. M., \& Harrison, R. T. (2000). The size of the informal venture capital market in the United Kingdom. Small Business Economics, 15(2), 137-148.

Mason, C. M., \& Harrison, R. T. (2015). Business angel investment activity in the financial crisis: UK evidence and policy implications. Environment and Planning C: Government and Policy, 33(1), 43-60.

North, D.C. (1990). Institutions, Institutional Change, and Economic Performance. Cambridge University Press, New York.

OECD (2011). Financing High-Growth Firms: The Role of Angel Investors. OECD Publishing. Available at: http://dx.doi.org/10.1787/9789264118782-en.

Roberts, R. (2015). Finance for Small and Entrepreneurial Business. Routledge. London.

Shane, S. (2012). The Importance of angel investing in financing the growth of entrepreneurial ventures. Quarterly Journal of Finance, 2(2), 1-42.

Stearns, L.B., \& Allan, K.D. (1996). Economic behavior in institutional environments: The corporate merger wave of the 1980s. American Sociological Review, 61(4), 699-718.

Storey, D. J., \& Tether, B. S. (1998). Public policy measures to support new technology-based firms in the European Union. Research Policy, 26(9), 1037-1057.

Tenca, F., Croce, A. \& Ughetto E. (2018). Business angels research in entrepreneurial finance: a literature review and a research agenda. Journal of Economic Surveys, forthcoming.

Tyebjee, T. T., \& Bruno, A. V. (1984). A model of venture capitalist investment activity. Management Science, 30(9), 1051-1066.

Veugelers, R. (2011). Mind Europe's early-stage equity gap (No. 2011/18). Bruegel policy contribution.

Wasserman, N. (2017). The throne vs. the kingdom: Founder control and value creation in startups. Strategic Management Journal, 38(2), 255-277.

Webb, J. W., Bruton, G. D., Tihanyi, L., \& Ireland, R. D. (2013). Research on entrepreneurship in the informal economy: Framing a research agenda. Journal of Business Venturing, 28(5), 598-614.

Wetzel, W. E. (1994). Venture capital. In: Portable MBA in entrepreneurship, Bygrave, W.D. (Ed.), 172-194, Wiley, New York. 
Wong, A., Bhatia, M., \& Freeman, Z. (2009). Angel finance: the other venture capital. Strategic Change, 18(7-8), 221-230.

Wu, J., Si, S., \& Wu, X. (2016). Entrepreneurial finance and innovation: Informal debt as an empirical case. Strategic Entrepreneurship Journal, 10(3), 257-273. 
Table 1. The effects of local financial systems on BA financing of innovative start-ups

\begin{tabular}{lcccr}
\hline \hline & \multicolumn{2}{c}{ At foundation } & & At survey time \\
\hline Column & I & II & III & IV \\
\hline Model & Probit & Tobit & Probit & Tobit \\
$\begin{array}{l}\text { Local Bank System } \\
\text { Development }\end{array}$ & $0.014(0.004)^{* * *}$ & $1.114(0.339)^{* * *}$ & $0.013(0.003)^{* * *}$ & $0.795(0.197)^{* * *}$ \\
Local VC Development & $22.588(12.570)^{*}$ & $1751.389(1043.200)^{*}$ & $33.447(10.153)^{* * *}$ & $1779.157(616.925)^{* * *}$ \\
Constant & $-2.854(0.287)^{* * *}$ & $-231.891(34.653)^{* * *}$ & $-2.615(0.231)^{* * *}$ & $-154.652(18.437)^{* * *}$ \\
No. of Obs. & 2184 & 2184 & 2184 & 2184 \\
Log-likelihood & -311.77 & -618.541 & -468.22 & -992.97 \\
\hline
\end{tabular}

Legend. Standard errors in round brackets. ${ }^{*} \mathrm{p}<.10 ;{ }^{* *} \mathrm{p}<.05 ;{ }^{* * *} \mathrm{p}<.01$. Tobit models in Columns II and IV are double-censored. 
Table 2. The effects of local financial systems on BA financing of innovative start-ups including control variables

\begin{tabular}{|c|c|c|c|c|}
\hline \multirow[b]{2}{*}{ Column } & \multicolumn{2}{|c|}{ At foundation } & \multicolumn{2}{|c|}{ At survey time } \\
\hline & I & II & III & IV \\
\hline Model & Probit & Tobit & Probit & Tobit \\
\hline Local Bank System Development & $0.028(0.009)^{* * *}$ & $1.658(0.624)^{* * *}$ & $0.024(0.007)^{* * *}$ & $1.104(0.360)^{* * *}$ \\
\hline Local VC Development & $66.324(33.213)^{* *}$ & $4054.02(2221.44)^{*}$ & $69.305(25.484)^{* * *}$ & $2930.11(1264.52)^{* *}$ \\
\hline High-tech Industry & $-0.072(0.106)$ & $-4.011(7.016)$ & $-0.049(0.080)$ & $-2.181(3.898)$ \\
\hline TEA & $-6.655(4.888)$ & $-466.04(326.25)$ & $-3.097(3.654)$ & $-127.64(178.34)$ \\
\hline Generic Human Capital & $-0.003(0.007)$ & $-0.179(0.464)$ & $-0.007(0.006)$ & $-0.186(0.279)$ \\
\hline Specific Human Capital & $-0.014(0.011)$ & $-0.985(0.718)$ & $-0.011(0.008)$ & $-0.412(0.403)$ \\
\hline Parent Entrepreneur & $0.068(0.186)$ & $1.938(12.374)$ & $0.122(0.150)$ & $5.690(7.336)$ \\
\hline International Experience & $0.255(0.109)^{* *}$ & $16.196(7.437)^{* *}$ & $0.298(0.089)^{* * *}$ & $14.439(4.460)^{* * *}$ \\
\hline Male Founders & $0.770(0.317)^{* *}$ & $45.985(21.063)^{* *}$ & $0.656(0.234)^{* * *}$ & $31.144(11.653)^{* * *}$ \\
\hline Team Size & $0.069(0.014)^{* * *}$ & $4.162(1.046)^{* * *}$ & $0.054(0.013)^{* * *}$ & $2.605(0.649)^{* * *}$ \\
\hline Incubation & $0.606(0.138)^{* * *}$ & $35.151(9.887)^{* * *}$ & $0.588(0.111)^{* * *}$ & $25.117(5.795)^{* * *}$ \\
\hline$S R L$ & $0.432(0.426)$ & $20.773(26.838)$ & $-0.062(0.270)$ & $-1.273(13.184)$ \\
\hline GDP per capita & $0.001(0.001)$ & $0.012(0.020)$ & $0.001(0.001)$ & $0.020(0.012)$ \\
\hline Regional Dummies & Yes & Yes & Yes & Yes \\
\hline Industry Dummies & Yes & Yes & Yes & Yes \\
\hline Constant & -13.802 (11.104) & -744.95 (733.68) & $-17.215(9.073)$ & $-899.65(448.18)^{* *}$ \\
\hline No of Obs. & 1726 & 1726 & 1726 & 1726 \\
\hline Log-likelihood & -217.36 & -487.32 & -341.95 & -803.94 \\
\hline
\end{tabular}

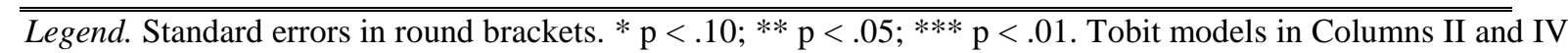
are double-censored. In Columns III and IV the variable GDP per capita is measured at firm foundation likewise in Columns I and II in order to increase the comparability of coefficients of the main independent variables across founding and survey time. 


\title{
On-line Appendix
}

\section{for}

There Must be An Angel? Local Financial Markets, Business Angels and the Financing of Innovative Start-ups

\author{
Luca Grilli
}

Politecnico di Milano

Department of Management, Economics, and Industrial Engineering

Via R. Lambruschini 4b, 20156, Milan, Italy. 


\section{Appendix A1. The Italian Startup Act}

As reported in the main text, the YIC status was and still is reserved to limited liability companies (either Italian companies or branches of EU companies registered in Italy), which are younger than 6 years (at the end of the sixth year their status as YIC ceases along with the possibility to obtain benefits), operate in high and medium technology-related businesses, and have an innovative content. Specifically, three requirements have to be fulfilled by an innovative start-up in order to gain the status of a YIC: (i) owner or licensee of a patent or a registered software or a generic intellectual right, (ii) at least one third of employees should hold a Ph.D. or a research tenure (or at least 66\% of the employees should possess a M.Sc. degree), (iii) investments in R\&D should account for at least 15\% of the revenues (or operating costs if they exceed the revenues). A company that qualifies as a YIC cannot distribute dividends and cannot be listed on a stock exchange. The annual revenues must be lower than $€ 5$ million and the company must not be originated from a spin-off or a merger of preexisting operations.

YICs (as identified by the Law) are granted specific incentives, exemptions and access to privileged (and discounted) services. The retroactive nature of the policy has also allowed access to these support measures not only to the ventures created after the promulgation of the Law, but also to those already existing before, provided that these firms fulfilled the prescribed requirements (including the requirement to be less than 6 years old). Measures span over different areas. For example, Italian YICs can be incorporated on the Internet through digital identification almost for free and they are exempted from any significant entry fee otherwise due to the Chambers of Commerce. Then, employees and consultants can be remunerated with stock options and "work for equity” tools enjoying particular reliefs. Moreover, Italian YICs may benefit from fail-fast mechanisms in case of liquidation, so to allow fresh new starts to entrepreneurs. Most notably for the domain of this study, the Law also contemplates benefits in the form of robust tax reliefs on equity investments made by legal entities and individuals: a $20 \%$ fiscal deduction up to a maximum investment of $€ 1.8$ million for legal entities, and a $19 \%$ deduction up to a maximum investment of $€$ 
0.5 million for individual investors. This provision aims at supporting VCs and BAs for the benefit of those YICs that receive this type of financing. A brief synopsis of the Law (and a comparison with similar legislations in other EU Member States) is provided by the European Digital Forum (2016). A complete description of the eligibility criteria and all support measures are available on the governmental website of MISE (http://www.mise.gov.it).

\section{Reference}

European Digital Forum (2016) The 2016 Startup Nation Scoreboard (London, U.K.). 


\section{Appendix A2}

Table A2. Geographical distribution of Italian BA-backed start-ups

\begin{tabular}{|c|c|c|c|c|c|}
\hline & \multicolumn{3}{|c|}{ At foundation } & \multicolumn{2}{|l|}{ At survey time } \\
\hline & N. firms & $\begin{array}{l}\text { N. of BA-backed } \\
\text { firms }\end{array}$ & $\%$ & N. of BA-backed firms & $\%$ \\
\hline \multicolumn{6}{|l|}{ Region } \\
\hline Abruzzo & 44 & 0 & 0.00 & 1 & 2.27 \\
\hline Basilicata & 16 & 1 & 6.25 & 1 & 6.25 \\
\hline Calabria & 53 & 0 & 0.00 & 1 & 1.89 \\
\hline Campania & 121 & 2 & 1.65 & 3 & 2.48 \\
\hline Emilia-Romagna & 249 & 11 & 4.42 & 17 & 6.83 \\
\hline Friuli Venezia Giulia & 66 & 1 & 1.52 & 4 & 6.06 \\
\hline Lazio & 192 & 8 & 4.17 & 17 & 8.85 \\
\hline Liguria & 32 & 0 & 0.00 & 0 & 0.00 \\
\hline Lombardia & 480 & 29 & 6.04 & 45 & 9.38 \\
\hline Marche & 85 & 0 & 0.00 & 0 & 0.00 \\
\hline Molise & 8 & 0 & 0.00 & 0 & 0.00 \\
\hline Piemonte & 163 & 8 & 4.91 & 11 & 6.75 \\
\hline Puglia & 80 & 2 & 2.50 & 2 & 2.50 \\
\hline Sardegna & 60 & 0 & 0.00 & 2 & 3.33 \\
\hline Sicilia & 93 & 0 & 0.00 & 1 & 1.08 \\
\hline Toscana & 129 & 3 & 2.33 & 7 & 5.43 \\
\hline Trentino Alto Adige & 99 & 5 & 5.05 & 10 & 10.10 \\
\hline Umbria & 32 & 0 & 0.00 & 0 & 0.00 \\
\hline Valle d'Aosta & 5 & 1 & 20.00 & 1 & 20.00 \\
\hline Veneto & 177 & 2 & 1.13 & 3 & 1.69 \\
\hline Total & 2184 & 73 & 3.34 & 126 & 5.77 \\
\hline
\end{tabular}




\section{Appendix A3}

\section{Table A3. Definition of explanatory variables}

Variable

Local Bank System Development

Local VC Development

High-tech Industry

TEA

Generic Human Capital

Specific Human Capital

Parent Entrepreneur

International Experience

Male Founders

Team Size

Incubation

SRL

GDP per capita

\section{Description}

Yearly average of the amount of bank credit loans over GDP granted to firms in the region (NUTS 2 level) over the time window 2008-2011 (source: ISTAT).

Yearly average of the amount of venture capital investments over GDP flown in the region (NUTS 2 level) over the time window 2008-2011 (source: ISTAT).

Average number of residents employed in high-tech and knowledge-intensive manufacturing sectors as a percentage of the total workforce of the region over the time window 2008-2011 (source: ISTAT).

Value of the Total Entrepreneurship Rate at regional (NUTS 2) level in the year of foundation of the firm (source: GEM).

Average number of years of experience among co-founders of the firm gained through education and work experience in other sectors with respect to the activity of the start-up, before firm's foundation.

Average number of years of experience among co-founders of the firm gained through work experience in the same sector of the start-up before firm's foundation and previous managerial and entrepreneurial experiences.

Average number of co-founders in the firm with parents who are (or were) entrepreneurs.

Averaged index across co-founders of the firm that ranges from 0 to 3 and counts if the entrepreneurs have matured any experience in a foreign country as an enrolled student, a pay-roll employee and an entrepreneur.

Percentage of male individuals among co-founders of the firm.

Number of co-founders of the firm.

Dummy that equals one if the firm has ever been located in a certified business incubator, zero otherwise.

Dummy that equals one for limited liability companies, zero otherwise.

National gross domestic product converted to dollars using purchasing power parity rates and divided by total population in the year of foundation of the firm (source: World Bank).

Legend. If not otherwise specified, the source of the variable is the Startup Survey. 


\section{Appendix $\mathrm{A}_{4}$}

Table A4. Descriptive statistics and correlation matrix

\begin{tabular}{|c|c|c|c|c|c|c|c|c|c|c|c|c|c|c|c|}
\hline \multicolumn{2}{|c|}{ Variable } & \multirow{2}{*}{$\begin{array}{c}\text { Mean } \\
61.001\end{array}$} & \multirow{2}{*}{$\frac{\text { S.D. }}{15.914}$} & \multirow{2}{*}{$\begin{array}{c}(1) \\
1.000\end{array}$} & \multirow[t]{2}{*}{ (2) } & \multirow[t]{2}{*}{ (3) } & \multirow[t]{2}{*}{ (4) } & \multirow[t]{2}{*}{ (5) } & \multirow[t]{2}{*}{ (6) } & \multirow[t]{2}{*}{ (7) } & \multirow[t]{2}{*}{ (8) } & \multirow[t]{2}{*}{ (9) } & \multirow[t]{2}{*}{$(10)$} & \multirow[t]{2}{*}{ (11) } & \multirow[t]{2}{*}{ (12) } \\
\hline (1) & Local Bank System Development & & & & & & & & & & & & & & \\
\hline (2) & Local VC Development & 0.005 & 0.004 & -0.0254 & 1.000 & & & & & & & & & & \\
\hline (3) & High-tech Industry & 3.350 & 1.530 & 0.3996 & 0.6705 & 1.000 & & & & & & & & & \\
\hline (4) & TEA & 0.040 & 0.021 & -0.3372 & -0.2620 & -0.3546 & 1.000 & & & & & & & & \\
\hline (5) & Generic Human Capital & 10.543 & 10.835 & 0.0647 & 0.0610 & 0.0903 & -0.0516 & 1.000 & & & & & & & \\
\hline (6) & Specific Human Capital & 9.185 & 8.075 & 0.0385 & -0.0070 & -0.0220 & -0.0434 & -0.4685 & 1.000 & & & & & & \\
\hline (7) & Parent Entrepreneur & 0.221 & 0.353 & 0.0288 & -0.0467 & -0.0048 & 0.0190 & -0.0807 & 0.0680 & 1.000 & & & & & \\
\hline (8) & International Experience & 0.348 & 0.538 & 0.0225 & 0.0336 & 0.0557 & -0.0176 & 0.1432 & -0.0468 & 0.0094 & 1.000 & & & & \\
\hline (9) & Male Founders & 0.828 & 0.302 & 0.0418 & -0.0001 & 0.0242 & -0.0448 & 0.0801 & -0.0469 & -0.0119 & 0.1094 & 1.000 & & & \\
\hline (10) & Team Size & 3.571 & 3.048 & 0.0153 & -0.0270 & 0.0007 & -0.0685 & -0.0502 & 0.0458 & -0.0787 & -0.0196 & 0.0027 & 1.000 & & \\
\hline (11) & Incubation & 0.279 & 0.448 & -0.0243 & -0.0190 & -0.0309 & -0.0508 & -0.0740 & -0.0198 & 0.0116 & 0.0207 & -0.0157 & 0.0387 & 1.000 & \\
\hline (12) & $S R L$ & 0.960 & 0.196 & 0.0147 & -0.0076 & 0.0097 & 0.0163 & 0.0217 & 0.0095 & 0.0452 & 0.0224 & 0.0599 & -0.2092 & 0.0213 & 1.000 \\
\hline (13) & GDP per capita & 35,696 & 218.23 & 0.0378 & 0.0536 & 0.0413 & -0.0861 & -0.0324 & 0.0443 & -0.0389 & -0.0060 & 0.0306 & 0.0114 & 0.0525 & -0.0164 \\
\hline
\end{tabular}

Legend. Descriptive statistics on the main independent variables computed on 2,184 firms. Descriptive statistics on control variables and correlation matrix based on 1,726 firms. 


\section{Appendix A5}

Table A5. Marginal effects and semi-elasticities of variables of interest

\begin{tabular}{|c|c|c|c|c|}
\hline \multirow[b]{2}{*}{ Column } & \multicolumn{2}{|c|}{ At foundation } & \multicolumn{2}{|c|}{ At survey time } \\
\hline & I & II & III & IV \\
\hline Model & Probit & Tobit & Probit & Tobit \\
\hline $\begin{array}{l}\text { Local Bank System } \\
\text { Development }\end{array}$ & $0.001(0.000)^{* * *}$ & $67.970(20.705)^{* * *}$ & $0.002(0.000)^{* * *}$ & $48.475(11.992)^{* * *}$ \\
\hline Local VC Development & $1.645(0.925)^{*}$ & $9.360(5.575)^{*}$ & $3.768(1.159)^{* * *}$ & $9.509(3.297)^{* * *}$ \\
\hline
\end{tabular}

Legend. Marginal effects (for probit) and semi-elasticities (for tobit) computed from models of Table $1 .{ }^{*} \mathrm{p}<.10 ;{ }^{* *} \mathrm{p}$ $<.05 ; * * * \mathrm{p}<.01$.

\section{Appendix A6. Robustness checks}

As we say in the main text, results have been subjected to several tests in order to gauge the reliability of the findings and they are exposed in the Table A6 below reported. We present results of these robustness tests on the probit models at survey time, but it is worthwhile to note that all the other models estimated (probit or tobit) at different moments (foundation or survey time) comply with these checks. First, we excluded from the sample the YICs that were born before the implementation of the Startup Act (Column I). In fact, one may suspect that these firms are particularly unlikely to receive the attention of BAs, given that they have self-selected themselves for the public support and this might be revealing of the lack of (already explored) alternative options to finance firms' operations. The exclusion of the innovative start-ups created in the year 2012 or before does not lead to any remarkable change in the findings. Secondly, we included the eventual use of alternative sources of financing by the innovative start-ups as additional regressors into the model specification (Column II). More specifically, through the use of the questionnaire, entrepreneurs were asked to indicate the percentage through which they finance operations of their firms across the following different financing modes: own resources, resources from family, fools and friends (3Fs), public subsidies granted at national level, public subsidies granted at regional level, equity financing provided by third parties (including VC), bank debt. Despite of the probable endogeneity of these regressors since they are likely to depend on whether or not YICs effectively get access to angel 
financing, a further (indirect) confirmation of our findings would be represented by the absence of any strong negative correlation between these alternative financing modes and BA financing. Results meet this expectation: the impact of the two variables of interest is still positive and strongly significant, while the existing correlations between these firm-specific financing modes and the probability of obtaining BA financing for an innovative start-up are always positive, and in most cases statistically significant, including the coefficients that refer to VC and bank debt. Then, findings do not appear to be driven by the North-South divide, since they are totally confirmed once southern regions are excluded from the estimations (Column III). They also hold in other three regressions where YICs located in North-West, North-East and the Centre of Italy are sequentially excluded from estimation. Analogously, results are unchanged if YICs located in Lombardia or in Milan (which represents the financial capital city of Italy and a pole of attraction for potential innovative entrepreneurs) are dropped (Column IV). Furthermore, following Dale and Fortin (2002), we used a plethora of different methods to check if our findings could be driven by the presence of spatial correlation in the structure of data. Accordingly, we re-run the main regression analysis by subsampling our data (by randomly picking some NUTS 2 regions and excluding the closest neighbour regions) and by using other recommended randomization or permutation techniques (i.e. bootstrapping and jack-knifing). Our main results are totally confirmed (see Column V for what concerns estimates of the model on a random sub-sample of 761 innovative start-ups located in 7 different non-neighbour regions; different combinations among non-neighbour regions lead to similar findings). In Column VI, we also tested if a generic availability at local level of business angel financing can be positively related to the probability for an innovative start-up to get a professional BA investment (as our definition implies). For this purpose, we resorted to the Global Entrepreneurship Monitor (GEM) data and created a brand new variable that captures the generic business angel activity in NUTS 2 regions as measured by the GEM survey, averaged over the same time window 2008-2011 used for the independent variables of interest. Findings about the main regressors are totally unaffected and the new variable shows a negative and largely insignificant 
impact. This is largely unsurprising given both the narrow definition of BAs which our study adopts (that point to "professionals”) and, conversely, the general concept of BA financing which applies to GEM (where the survey item used is: "Have you, in the past three years, personally provided funds for a new business started by someone else, excluding any purchases of stocks or mutual funds?”). At the same time, this negligible impact can also be viewed as another indirect confirmation that external equity investments in innovative start-ups are especially enabled only by strong and professionalized local financial markets. Finally, despite of the fact that clustering standard errors in non-linear settings is not immune from critiques, especially when the number of clusters is limited (e.g. Angrist and Pischke, 2008, p. 319), we checked whether clustering standard errors at the regional level could make any difference on our findings. As shown in Column VII, the results (and their significance) are largely unaffected by the choice.

Then, in unreported (but available upon request) regressions we checked for several other potential empirical issues. For example, we also inspected whether our results could be driven by the specific time-window (2008-2011) we chose for the main independent variables. Therefore, we both re-run regressions using different time-spans for both Local Bank System Development and Local VC Development, and results again do not remarkably change from those already commented. In the same vein, we inspected whether the inclusion into the regressions (whether probit or tobit) of a series of year dummies that capture possible time-varying idiosyncratic shocks at YICs’ foundation time could affect our findings and exclude this possibility. Then, we also verified if the substitution of the regional-specific controls we used with other equally possible alternatives could lead to significant changes. For instance, we substituted the covariate High-tech Industry with the variable Science and Technology Education that represents the number of graduates in science and technology subjects per thousand of inhabitants with an age in-between 20 and 29 years old (source: ISTAT). The two variables are highly correlated, albeit not perfectly collinear (pairwise correlation equal to 0.65) and perform rather similarly. Additionally, we used GDP per capita at regional level and Number of active firms in a region as proxies for regional economic development. Results as to the main 
independent variables remain unchanged and again confirm the weak statistical influence of these controls on the dynamics of interest. We also decomposed the TEA index into its opportunity and necessity components, to discover that again findings remain unaltered, with the opportunity component that leads to a positive impact and the necessity component to a negative one, but in both cases, the effects are largely statistically insignificant. Finally, both the use of the current value of the TEA index in place of the value anchored to the start-up foundation year and the omission of the variable GDP per capita in the regressions at survey time, do not change the findings exposed here.

\section{References}

Angrist, J. D., \& Pischke, J. (2008). Mostly Harmless Econometrics; an Empiricist's Companion, 1st ed. Princeton University Press. Princeton.

Dale, M. R., \& Fortin, M. J. (2002). Spatial autocorrelation and statistical tests in ecology. Ecoscience, 9(2), 162-167. 
Table A6. Robustness checks

\begin{tabular}{|c|c|c|c|c|c|c|c|}
\hline Column & I & II & III & IV & V & VI & VII \\
\hline Check & $\begin{array}{c}\text { Excluding } \\
\text { YICs born } \\
\text { before } \\
2013\end{array}$ & $\begin{array}{l}\text { Alternative } \\
\text { sources of } \\
\text { financing }\end{array}$ & $\begin{array}{c}\text { Excluding } \\
\text { southern } \\
\text { YICs }\end{array}$ & $\begin{array}{l}\text { Excluding } \\
\text { YICs from } \\
\text { Milan }\end{array}$ & $\begin{array}{l}\text { YICs in non- } \\
\text { neighbour } \\
\text { regions }\end{array}$ & $\begin{array}{c}\text { Controlling } \\
\text { for generic } \\
\text { BAs at local } \\
\text { level }\end{array}$ & $\begin{array}{l}\text { Clustered } \\
\text { standard } \\
\text { errors at } \\
\text { regional } \\
\text { level }\end{array}$ \\
\hline $\begin{array}{l}\text { Local Bank } \\
\text { System } \\
\text { Development }\end{array}$ & $\begin{array}{c}0.013 \\
(0.004)^{* * *}\end{array}$ & $\begin{array}{c}0.013 \\
(0.004)^{* * *}\end{array}$ & $\begin{array}{c}0.012 \\
(0.005)^{* *}\end{array}$ & $\begin{array}{c}0.009 \\
(0.003)^{* * *}\end{array}$ & $\begin{array}{c}0.016 \\
(0.007)^{* *}\end{array}$ & $\begin{array}{c}0.012 \\
(0.003)^{* * *}\end{array}$ & $\begin{array}{l}0.013 \\
(0.003)^{* * *}\end{array}$ \\
\hline $\begin{array}{l}\text { Local VC } \\
\text { Development }\end{array}$ & $\begin{array}{c}35.519 \\
(11.408)^{* * *}\end{array}$ & $\begin{array}{c}40.212 \\
(11.504)^{* * *}\end{array}$ & $\begin{array}{c}30.034 \\
(11.583)^{* * *}\end{array}$ & $\begin{array}{c}34.196 \\
(10.282)^{* * *}\end{array}$ & $\begin{array}{c}48.039 \\
(15.322)^{* * *}\end{array}$ & $\begin{array}{c}38.894 \\
(10.956)^{* * *}\end{array}$ & $\begin{array}{l}33.447 \\
(9.542)^{* * *}\end{array}$ \\
\hline $\begin{array}{l}\text { Own personal } \\
\text { funds }\end{array}$ & & $0.002(0.003)$ & & & & & \\
\hline $3 F s$ & & $\begin{array}{c}0.014 \\
(0.005)^{* * *}\end{array}$ & & & & & \\
\hline $\begin{array}{l}\text { National } \\
\text { Subsidies }\end{array}$ & & $0.008(0.005)^{*}$ & & & & & \\
\hline $\begin{array}{l}\text { Regional } \\
\text { Subsidies }\end{array}$ & & $\begin{array}{c}0.011 \\
(0.004)^{* *}\end{array}$ & & & & & \\
\hline$V C$ & & $\begin{array}{c}0.021 \\
(0.003)^{* * *}\end{array}$ & & & & & \\
\hline Bank debt & & $0.005(0.003)^{*}$ & & & & & \\
\hline $\begin{array}{l}\text { Local availability } \\
\text { of generic BA } \\
\text { financing }\end{array}$ & & & & & & $-4.666(3.250)$ & \\
\hline Constant & $\begin{array}{c}-2.693 \\
(0.261)^{* * *}\end{array}$ & $\begin{array}{c}-3.288 \\
(0.392)^{* * *}\end{array}$ & $\begin{array}{c}-2.503 \\
(0.395) * * *\end{array}$ & $\begin{array}{c}-2.414 \\
(0.237)^{* * *}\end{array}$ & $\begin{array}{c}-2.986 \\
(0.524)^{* * *}\end{array}$ & $\begin{array}{c}-2.429 \\
(0.264)^{* * *}\end{array}$ & $\begin{array}{c}-2.615 \\
(0.230)^{* * *}\end{array}$ \\
\hline No of Obs. & 1857 & 2184 & 1709 & 1913 & 761 & 2184 & 2184 \\
\hline Log-likelihood & -360.704 & -365.400 & -416.898 & -360.704 & -156.02 & -467.17 & -468.22 \\
\hline
\end{tabular}

Legend. Standard errors in round brackets. ${ }^{*} \mathrm{p}<.10 ;{ }^{* *} \mathrm{p}<.05 ; * * * \mathrm{p}<.01$. All probit models refer to survey time. 